\title{
GAMBARAN TINGKAT PENGETAHUAN REMAJA TENTANG SEKS BEBAS PADA MASA PADEMI COVID-19 DI SMP NEGERI 4 PUPUAN
}

\author{
Made Dewi Sariyani ${ }^{1,2}$, Kadek Sri Ariyanti ${ }^{1,2}$, Ni Wayan Puspitasari ${ }^{1,2}$ \\ ${ }^{1}$ Program Studi Diploma III Kebidanan, ${ }^{2}$ STIKES Advaita Medika Tabanan \\ Korespondensi: sariyani27@ymail.com
}

\begin{abstract}
Abstrak
Latar belakang: Seks bebas bebas merupakan salah satu permasalahan remaja yang harus mendapat perhatian yang khusus. Tingginya angka seks bebas pada remaja dipengaruhi oleh berbagai faktor, salah satunya adalah pengetahuan yang kurang terkait seks bebas.

Tujuan: Penelitian ini bertujuan untuk mengetahui gambaran tingkat pengetahuan remaja tentang seks bebas di SMP Negeri 4 Pupuan.

Metode: Jenis penelitian ini adalah deskriptif dengan rancangan cross sectional. Jumlah populasi sebanyak 299 orang siswa, sampel dalam penelitian ini berjumlah 171 orang, pengambilan sampel dengan cara random sampling, uji statistik menggunakan SPSS. Instrumen dalam penelitian ini menggunakan kuesioner yang disebarkan secara online melalui google form. Analisa data dengan cara deskriptif untuk memperoleh distribusi frekuensi variabel.

Hasil: Dari hasil penelitian diperoleh tingkat pengetahuan remaja tentang seks bebas dalam kategori cukup baik yaitu sebanyak $75 \%$.

Simpulan: Tingkat pengetahuan remaja tentang seks bebas SMP Negeri 4 Pupuan mengenai seks bebas sudah baik.
\end{abstract}

Kata kunci: Pengetahuan, Remaja, Seks Bebas

\section{Pendahuluan}

Usia remaja merupakan masa peralihan dari anak-anak menuju dewassa (Wong,2015), menjelaskan bahwa masa remaja merupakan masa terjadinya tahap perkembangan yang paling pesat, dibandingkan dengan tahap perkembangan lainnya.

Data statistik PBB memperlihatkan sebanyak 16 juta gadis remaja di dunia yang berusia di bawah 18 tahun melahirkan setiap tahunya, sebanyak 3,2 juta remaja menjalani aborsi yang tidak aman, kehamilan di kalangan remaja sering disebabkan oleh diskriminasi pelanggaran hak (termasuk pernikahan dini, pendidikan yang tidak layak, hubungan seks secara paksa ). Survei dari beberapa negara berkembang tahun $2017^{1}$ bahwa di negara Liberti, yaitu remaja putri menunjukkan $46 \%$ usia $14-17$ tahun dan
$66,2 \%$ remaja putra sudah saling bersenggama (WHO, 2016).

Studi di Bali memperoleh hasil remaja laki - laki Sekolah Menengah Pertama (SMP) dan Sekolah Menengah Atas (SMA) lebih banyak berhubungan seks pranikah (40,3\% dan $29,4 \%)$ dibandingkan dengan remaja perempuan $(3,6 \%$ dan $12,5 \%)$. Remaja laki - laki di Bali lebih permisif terhadap prilaku seks pranikah (Dinkes 2011). Berdasarkan hasil studi pendahuluan pada tanggal 8 Maret 2021 di SMP N 4 Pupuan, di dapatkan informasi dari staf Tata Usaha (TU) dan guru bimbingan konseling (BK) dari hasil wawancara dengan pihak sekolah di ketahui sebanyak 10 orang siswa jarang mengikuti pelajaran, 3 orang di antaranya putus sekolah dan belum diketahui secara ${ }^{2}$ pasti penyebab dari siswa terebut, 1 orang siswa berhenti karena hamil di luar nikah. Dari hasil wawancara yang diajukan ke siswa 
siswi lewat pembagian koesioner jumlah total siswa sebanyak 299 orang, dan pengambilan responden sebanyak 171 orang, sebagian diantaranya tingkat pengetahuan tentang seks bebas di masa pademi COVID19 cukup baik walapun diantaranya masih ada yang memiliki pengetahuan yang rendah.

\section{Metode Penelitian}

Penelitian yang dilakukan merupakan penelitian deskriptif sederhana dengan pendekatan cross sectional . Deskriptif adalah suatu mtode penelitian yang dilakukan dengan tujuan utama untuk membuat gambaran atau deskripsi tentang suatu keadaan secara objektif dan digunakan untuk memecah situasi yang sedang dihadapi saat ini (Notoatmodjo,2011). Dalam metode deskriptif sederhana ini data yang ditemukan disajikan apa adanya, tidak memerlukan analisis sehingga tidak diperlukan uji hipotesis.

\section{Hasil dan Pembahasan}

Tabel 1. Karakteristik Responden

\begin{tabular}{llll}
\hline No. & Karakteristik & Frekuensi (f) & Persentase (\%) \\
\hline 1 & Umur & & \\
& 13 tahun & 38 & $22.2 \%$ \\
& 14 tahun & 58 & $33,9 \%$ \\
& 15 tahun & 61 & $35,7 \%$ \\
& 16 tahun & 14 & $8,2 \%$ \\
& Total & 171 & $100 \%$ \\
\hline 2 & Jenis Kelamin & & \\
& Laki-laki & 65 & $38,1 \%$ \\
& Perempuan & 106 & $61,9 \%$ \\
& Total & 171 & $100 \%$ \\
\hline 3 & Kurang Baik & 20 & $18,0 \%$ \\
& Cukup Baik & 106 & $61,9 \%$ \\
& Baik & 45 & $20,1 \%$ \\
& Total & 171 & $100 \%$ \\
\hline
\end{tabular}

Tabel 2. Tingkat Pengetahuan Remaja Tentang Seks Bebas

\begin{tabular}{llll}
\hline No. & Pengetahuan & Frekuensi (f) & Persentase (\%) \\
\hline 1 & Pengetahuan tentang seks bebas & & \\
& Tahu & 94 & $77,0 \%$ \\
& Tidak Tahu & 77 & $23,0 \%$ \\
& Total & 171 & $100 \%$ \\
\hline 2 & Pengertian seks bebas & 77 & $45,1 \%$ \\
& Tahu & $74,9 \%$ \\
& Tidak tahu & 94 & $100 \%$ \\
\hline & Total & 171 & $87,1 \%$ \\
& Bentuk-bentuk seks bebas & 149 & $12,9 \%$ \\
& Tahu & 22 & $100 \%$ \\
\hline & Tidak tahu & 171 & \\
& Total & & $77,8 \%$ \\
& Faktor-faktor seks bebas & 127 & $22,2 \%$ \\
& Tahu & 44 & $100 \%$ \\
\hline & Tidak tahu & 171 & \\
& Total & & $77,8 \%$ \\
\hline 5 & Dampak seks bebas & 133 & $22,8 \%$ \\
& Tahu & 38 & $100 \%$ \\
& Tidak tahu & 171 & \\
& Total & &
\end{tabular}




\begin{tabular}{lll}
\hline 6 & Pencegahan seks bebas & \\
Tahu & 162 & $94,0 \%$ \\
Tidak tahu & 9 & $6,0 \%$ \\
Total & 171 & $100 \%$ \\
\hline
\end{tabular}

Berdasarkan data yang disampaikan pada tabel 1 dari 171 responden sebagian besar responden tingkat pengetahuan remaja tentang seks bebas cukup baik yaitu sebanyak 94 orang $(77,0 \%)$ tahu tentang pengetahuan remaja tentang seks bebas. Sedangkan berdasarkan tujuan khusus tingkat pengetahuan remaja tentang seks bebas yang meliputi pengertian tentang seks bebas memliki kategori kurang baik yaitu sebagian besar tidak tahu yaitu sebanyak 94 orang $(54,9 \%)$ dari 171 responden. Tingkat pengetahuan remaja tentang bentuk-bentuk seks bebas memiliki kategori baik yaitu sebanyak 149 orang $(87,1 \%)$ dari 171 responden.

Tingkat pengetahuan remaja tentang faktor-faktor seks bebas memiliki kategori baik yaitu sebanyak 127 orang $(77,8 \%)$ dari 171 responden. Tingkat pengetahuan remaja tentang dampak seks bebas memiliki kategori baik yaitu sebanyak 133 orang $(77,8 \%)$ dari 171 responden. Tingkat pengetahuan remaja tentang pencegahan seks bebas memiliki kategori baik yaitu sebanyak 162 orang $(94,0 \%)$ dari 171 responden.

\section{Pengetahuan Tentang Seks Bebas}

Hasil penelitian gambaran tingkat pengetahuan remaja tentang seks bebas di SMP Negeri 4 Pupuan menujukkan bahwa cukup baik yaitu sebanyak 94 orang $(77,0 \%)$ tahu tentang pengetahuan remaja tentang seks bebas. Data tersebut di dapat dari pembagian koesioner melalui google form. Menurut teori pengetahuan adalah hasil pengindraan manusia, atau hasil tau seseorang terhadap objek melalui indra yang kita dimilikinya seperti mata, hidung, telingga dan sebagainya untuk menghasilkan pengetahuan dan keterampilan (Notoatmodjo, 2011).

Pengertian

Hasil penelitian gambaran tingkat pengetahuan remaja tentang seks bebas di
SMP Negeri 4 Pupuan terkait pengertian menujukkan bahwa $45,1 \%$ tidak tau tentang pengertian seks bebas sekitar 171 responden kurang tepat menjawab pertanyaan tersebut. Data tersebut di dapat dari pembagian koesioner melalui google form. Dalam konsep pengertian seks bebas merupakan kebiasaan melakukan seksual secara bebas dilakukan oleh mereka yang menentang atau merasa enggan jika diri mereka terikat dalam suatu pernikahan yang suci. Orang yang telah mempertaruhkan hawa nafsunya sendiri, akan merasa sangat tidak puas jika menyalurkan nafsu biologisnya kepada istri atau suami sahnya saja (Tanjung, 2011).

Bentuk-Bentuk Seks Bebas

Hasil penelitian gambaran tingkat pengetahuan remaja SMP Negeri 4 Pupuan, terkait bentuk-bentuk seks bebas menunjukkan bahwa sebagian besar tingkat pengetahuan siswa sudah relatif baik. Data tersebut di dapat dari pembagian koesioner melalui google form. Menurut Sarwono (2011), juga mengemukakan beberapa bentuk dari perilaku seks bebas, yaitu: Kissing, Necking, Petting, dan intercourse. Bentuk-bentuk perilaku seks bebas yang disebutkan Sarwono kebanyakan remaja sebagian besar sudah memahami dengan baik hal ini sesuai dengan hasil penelitian terkait bentuk-bentuk seks bebas menunjukkan bahwa $87,1 \%$ responden memiliki tingkat pengetahuan baik.

Faktor-Faktor Yang Mempengaruhi Seks Bebas

Hasil penelitian gambaran tingkat pengetahuan SMP Negeri 4 Pupuan, terkait faktor yang mendorong perilaku seks bebas menunjukkan bahwa $85 \%$ responden memiliki tingkat pengetahuan baik. Hal ini dibuktikan dari 171 responden yang memiliki tingkat pengetahuan baik mengenai faktor yang mendorong perilaku seks bebas sekitar 127 responden dapat 
menjawab pertanyaan dengan benar. Jumlah ini lebih tinggi jika dibandingkan dengan kategori pemahaman mengenai bentuk-bentuk seks bebas. Data tersebut di dapat dari pembagian koesioner melalui google form.

Menurut Sarwono (2013), Dorongan seksual pada masa remaja disebabkan karena beberapa faktor yang dianggap berperan dalam munculnya permasalahan seksual,diantaranya perubahan-perubahan hormonal yang dapat meningkatkan hasrat seksual remaja, penyebaran informasi yang salah misalnya dari bukubuku dan VCD porno, rasa ingin tahu yang sangat besar, serta kurangnya pengetahuan yangdidapat dari orang tua dikarenakan orang tua menganggap hal tersebut tabu untuk dibicarakan.

\section{Dampak Seks Bebas}

Hasil penelitian gambaran tingkat pengetahuan remaja SMP Negeri 4 Pupuan, terkait dampak seks bebas menunjukkan bahwa sebagian besar tingkat pengetahuan siswa sudah relatif baik, dari 171 responden $77,8 \%$ responden sudah mengetahui apa dampak dari seks bebas. Data tersebut di dapat dari pembagian koesioner melalui google form. Hubungan seks pranikah mengakibatkan penularan PMS, HIV-AIDS, kehamilan di luar nikah, dan aborsi tidak aman (Masland 2014).

\section{Pencegahan Seks Bebas}

Hasil penelitian gambaran tingkat pengetahuan remaja SMP Negeri 4 Pupuan, terkait pencegahan seks bebas menunjukkan bahwa sebagian besar tingkat pengetahuan siswa sudah relatif baik, dari 171 responden 94,0 \% responden sudah mengetahui apa cara pencegahan dari seks bebas. Data tersebut di dapat dari pembagian koesioner melalui google form. Faktor keluarga sangat menentukan dalam masalah pendidikan seks sehingga perilaku seks bebas dapat dihindari, kedekatan anak dengan orang tua berpengaruh dalam pendidikan anak dalam pencegahan seks bebas (Sarwono,2013).

\section{Simpulan}

Secara keseluruhan tingkat pengetahuan remaja tentang seks bebas SMP Negeri 4 Pupuan mengenai seks bebas sudah baik. Mengacu pada tujuan penelitian yang telah disusun dan ditetapkan sebelum pelaksanaan penelitian ini, maka peneliti mendapatkan kesimpulan sebagai berikut:

a. Gambaran tingkat pengetahuan remaja tentang seks bebas dimasa pandemi COVID-19 di SMP Negeri 4 Pupuan sebagian besar dalam kategori cukup baik yaitu sebanyak $75,0 \%$.

b. Gambaran tingkat pengetahuan remaja tentang pengertian seks bebas, hasil yang diperoleh menunjukkan bahwa sebagian memliki pengetahuan yang kurang baik sebanyak 54,9\%.

c. Gambaran tingkat pengetahuan remaja tentang bentuk-bentuk seks bebas, hasil yang diperoleh menunjukkan bahwa sebagian besar sudah mengetahui bentukbentuk seks bebas sebanyak $87,1 \%$.

d. Gambaran tingkat pengetahuan remaja tentang faktor-faktor yang mendorong seks bebas, hasil yang diperoleh menunjukkan bahwa sebagian besar sudah mengetahui faktor-faktor yang mendorong seks bebas sebanyak $77,8 \%$.

e. Gambaran tingkat pengetahuan remaja tentang dampak seks bebas, hasil yang diperoleh menunjukkan bahwa sebagian besar sudah mengetahui dampak seks bebas sebanyak $77,8 \%$.

f. Gambaran tingkat pengetahuan remaja tentang pencegahan seks bebas, hasil yang diperoleh menunjukkan bahwa sebagian besar sudah mengetahui pencegahan seks bebas sebanyak $94,0 \%$.

\section{Referensi}

Bukhari Y.S. 2016., Psikologi Praktis: Anak, Remaja dan Keluarga, Jakarta: BPK Gunung Mulia.

Depkes 2011. Kesehatan Remaja. Jakarta: Salemba Medika.

Dinkes 2011. Laporan Tahuan Dinas Kesehatan Provinsi Bali. 
Desmita ,2015. Kesehatan Reproduksi. Yogyakarta: Sekolah Pascasarjana UGM.

Hurlock, E.B., Perkembangan Anak, Jilid I Edisi ke-6, Jakarta: Erlangga, 2017

Hurlock. E.B., Psikologi Perkembangan Suatu Pendekatan Sepanjang Rentang Kehidupan, Jakarta: Erlangga, Kencana.

Hastono,2012. Psikologi Perkembangan: Pengantar dalam Berbagai Bagian, Yogyakarta: Gadjah Mada University Press.

Kartono,2019, Psikologi Pendidikan, Edisi Revisi, Jakarta: Grasindo

Kartono, Kartini. 2019. Psikologi Abnormal dan Abnormalitas Seksual. Bandung: Mandar Maju.

Lerner, 2014. Apa yang ingin diketahui remaja tentang seks. Jakarta: Bumi Aksara.

Maria, 2017 Psikologi Perkembangan, Jakarta: Kencana.

Nenggala, 2017. Asertivitas dan Tahap Perkembangan Remaja Pada Anak Binaa.

Notoadmojo, 2018. Psikologi Remaja, Surabaya: Usaha Nasional

Tanjung, 2011. Definisi Perilaku Seks Bebas, Jawa Tengah.

Rintyastini, Y, Charlotte, SY. 2006. Bimbingan dan Konseling SMP Kelas VII. Jakarta: Erlangga.

Sarwono. S.W. 2013. Psikologi Remaja. Jakarta: Raja Grafindo Persada.

Sastroasmoro, 2011 Psikologi Praktis: Anak, Remaja dan Keluarga, Jakarta: BPK Gunung Mulia.

WHO, Klasifikasi Remaja. World Health Organization. 2018.

Wong 2015. Definisi Perilaku Seks Bebas. Makalah (Online) 